using semistructured interviewing, or ethnographic methods, is that the researcher suspects that the respondents view the world in very different ways from the researchers, and are capable of telling about their views. This strategy paid off--we found some rather surprising differences in the way experts and voters see several environmental issues.

In some ways, the most telling criticism of the review is that this volume is consistent with "books written by people funded by NSF, NOAA and NASA." With slurs like this, who needs compliments? We are glad to have our work compared with some of the best researchers in this area--whether physical science or social science. We are pleased to have made a small contribution to putting social science on the platform with the natural sciences, taking a serious part in understanding human dimensions of environmental change. We're guilty as charged.

\title{
THE FUTURE OF THE ENVIRONMENT: Ecological Economics and Technological Change, by Faye Duchin and Glenn-Marie Lange, with Knut Thonstad and Annemarth Idenburg. New York: Oxford University Press (1994). xiii, 222 pp.
}

\author{
Reviewed by Jae Edmonds, Senior Research Scientist, Pacific \\ Northwest Laboratories, Washington DC
}

The principle of "sustainable development," as articulated in the Brundtland Commission report (1987) encompasses the pursuit of economic well being in the present without compromising the ability of future generations to provide for their own well being. But while the general principle of "sustainable development" is one to which everyone subscribes, it is by no means clear how this principle should be implemented in the real world of scarcity. At the very heart of the problem of achieving "sustainable development" is the essence of the economic problem, the allocation of scarce resources to competing ends in the present and over time. It does not make the problem easier that one of the resources to be allocated is the environment.

In The Future of the Environment, Duchin and Lange therefore set out to explore this intellectual territory, and specifically the problem of simultaneously providing economic goods and services in increasing measure to an expanding fraction of the worlds people and the protection of the environment for ourselves and future generations. The authors are well qualified for this undertaking. Faye Duchin is the Director of the Institute for Economic Analysis at New York University, and Vice President of the International Society for Ecological Economics. She has taken up the work that was initiated by her Institute's founder, Nobel Laureate, Wassily Leontief. Glenn-Marie Lange is a colleague of Duchins at the Institute for Economic Analysis.

The work presented in this book was carried out over the three years leading up to the Earth Summit in Rio de Janeiro in June 1992 (Duchin et al., 1992). To understand and appreciate this book, the reader should recognize from the outset that the bounds of the 
problem that Drs. Duchin and Lange have taken on, although broad, are not unlimited, and somewhat different from what one might imagine from the book title alone. The central focus of the book is the interactions of the economy, technology and industrial emissions of carbon, sulfur, and nitrogen oxides. The three gases are used as indicators of anthropogenic impacts on global and regional environmental systems, but the mechanisms by which anthropogenic by-products affect the environment are left outside the boundaries of the book. For example the issues of demographics, the interaction between human activities, land-use change and anthropogenic emissions, or agricultural emissions, are not considered. Neither are the impacts of anthropogenic activities, such as on biodiversity, climate change, acidification, or $\mathrm{CO} 2$ fertilization. The boundary of the work is the industrial smokestack. This is an observation and not a criticism. Research without boundaries descends into uninteresting generalities. The book also limits its focus to the next thirty years, 1990 to 2020 . This is a period in which important changes will be taking place, and it is therefore a critical slice of time. From the perspective of long-term environmental issues such as climate change, however, this focus is rather shorter than most global studies have adopted. The book is laid out in two parts. The first part, entitled Methods and Results, presents an overview of the Our Common Future (OCF) scenario which was developed to explore the implications of changes in technology for the economy and emissions of three gases.

The power and usefulness of this book comes from three sources, the discipline of the global modeling system the authors have adopted, the data base that undergirds it, and attention to detail as demonstrated in the case studies that populate the second and largest part of the book. The book is very strong on its presentation of data including both the assumptions that go into scenario development and model results. The authors have assembled a wealth of information, which is made available here for fellow researchers and decision makers alike.

The authors employ a Leontief model of the global economy--specifically; Leontiefs model as set out in Leontief et al. 1977. This framework offers tremendous insights into the interconnectedness of economies, and insures a consistency that cannot be guaranteed outside of a framework in which physical and financial accounts are forced to balance.

Although the book is rich in detail about the potential evolution of the global economy, the authors in letting the results speak for themselves, leave the reader the task of assessing what to make of all this work. But it is easy to get lost in the details. Drs. Duchin and Lange are clearly closer to this issue than anyone else, and their opinions and assessments would be most welcome. In contrast, many books on similar subjects contain nothing but opinions, and their lack of analysis and research leave serious readers feeling empty. Duchin and Lange offer some thoughts in the early chapters of the book that serve to whet our appetite for more. For example, the authors put forward a conclusion that there are serious problems with achieving sustainable development. But the leap from the book's details to the final conclusion is too great. Why does this research lead the authors to that conclusion? What are the tradeoffs between economy, technology and the environment? At the end of the 13 data-rich chapters the book simply ends with a case study of transportation, and moves immediately to technical appendices and references without stopping to sum up. A concluding chapter rewarding the reader for persevering through the preceding ten score pages would have been a valuable addition.

Nevertheless, the book has a great deal to offer to the reader interested in a serious, detailed discussion of the forces shaping the first quarter of the next century. 


\section{References}

Brundtland Commission.

1987 Our Common Future. World Commission on Environment and Development. Oxford and New York: Oxford University Press.

Duchin, F., G. Lange, K. Thonstad, and A. Idenburg.

1992 Environmentally Sound Strategies for Economic Development: An Input-Output Analysis. Final Report to the United Nations under contract \#CTPS/CON/112/91.

Leontief, W., A. Carter, and P. Petri.

1977 Future of the World Economy. New York: Oxford University Press.

\section{When Capitalists Collide: Business Conflict and the End of Empire in Egypt. By Robert Vitalis. Berkeley: University of California Press, 1995. 282 pp.}

\section{Reviewed by Kirk Beattie, Department of Political Science and International Relations, Simmons College, Boston, MA.}

With this book, Robert Vitalis has made an important and novel contribution to the literature on newly industrializing countries. The novelty of his approach is reflected, first of all, by his decision to focus on investors as political and economic agents, and second, by his presentation of an alternative model for analyzing interest conflict and industrial development.

As Vitalis notes, most scholars of developing countries have assumed a zero-sum clash of imperialist and nationalist business interests. In addition, many scholars have assumed that the classic European developmental pattern, with its significant intersectoral (rural vs. urban interests) or class fraction-based confrontations, serves as an important guide for understanding the developmental path of late developers. For example, in the case of Egypt the common heretofore accepted wisdom (the work by Anwar Abdel-Malek [1968] is perhaps most noteworthy in this regard) has been that industrial development was blocked by British imperialist interests, that a private Egyptian challenge to those interests appeared in the form of the Bank Misr group in the 1920s, but that Bank Misr types ultimately proved incapable of playing the expected, classic role as builders of national capitalism and democracy, and were forced to take on stronger, Western imperialist partners. This, in turn, left the country languishing under the authoritarian rule of large landed interests, headed up by the monarch, who was backed by British imperialist guns. More "serious" attempts to industrialize Egypt could not occur until both the king and the British yoke had been removed, objectives that were realized in the aftermath of the 1952 military coup.

Vitalis succeeds in debunking this common vision of Egypt's developmental record, greatly improving upon the solid efforts by Davis (1983) and Tignor (1984). Though 